\title{
Diferenças entre Ética e Moral
}

\section{Differences between Ethics and Morals}

\section{Resumo}

A Ética é temática pertinente em diversas áreas de conhecimento, fomentando reflexões acerca de seu escopo, conceito, suas diferenças em relação ao conceito de moral e sua existência ou inexistência na sociedade atual brasileira. Nessa perspectiva, o presente estudo objetiva analisar o conceito, escopo, a relação com a moral e a existência ou inexistência no contexto social brasileiro da Ética. Para tal, utilizou-se de pesquisa bibliográfica. As discussões e resultados estão divididos em três tópicos, a saber: Ética, escopo e conceito; Diferenças entre Ética e moral, A Ética no Brasil e as conclusões e impressões da autora, nas considerações finais.

Palavras-chave: Conceito; Ética; Moral; Diferenças; Brasil.

\begin{abstract}
Ethics is a relevant theme in several areas of knowledge, promoting reflections about its scope, concept, its differences in relation to the concept of morality and its existence or non-existence in the current Brazilian society. From this perspective, the present study aims to analyze the concept, scope, the relationship with morality and the existence or non-existence in the Brazilian social context of Ethics. To this end, a bibliographic research was used. Discussions and results are divided into three topics, namely: Ethics, scope and concept; Differences between Ethics and morals, Ethics in Brazil and the author's conclusions and impressions, in the final considerations.
\end{abstract}

Keywords: Concept; Ethic; Moral; differences; Brazil.

\section{Introdução}

O conceito de Ética, complementado com o de moral, tecem as relações humanas mediante comportamentos, sendo bons e maus ao longo de tempo. Todavia, no decorrer da história e das transformações, a utilização dos termos ética e moral receberam formas distintas mesmo que permaneçam como sinônimos em alguns momentos (Rezende, 2006).

A Ética é temática pertinente nas diversas áreas de conhecimento. Nesse contexto, algumas reflexões acerca de seu conceito, escopo, diferenças em relação ao termo moral e sua existência ou falta dela na sociedade brasileira apresentam-se como pertinentes. 
Nessa perspectiva, o presente estudo objetiva, de forma breve, analisar o conceito, escopo, a relação com a moral e a existência ou inexistência no contexto social brasileiro da Ética. Para tal, utilizou-se de pesquisa bibliográfica como conceituada em Gil (2008).

\section{2. Ética, Escopo e Conceito}

O termo ética apresenta origem grega e latina, tendo como raiz etimológica o termo ethos, que apresenta duas grafias e significados distintos: uma diz respeito ao lugar onde se guardavam os animais, evoluindo para o lugar onde nasce a interioridade do homem (Renaud, 1994 apud Pedro, 2014); e a segunda significa a habitação do ser, comportamento, hábitos, caráter, modo de ser de uma pessoa (Pedro, 2014).

A ética tem característica especulativa. Sendo assim, não oferece fórmulas prontas para se adquirir e viver em sucesso, preocupa-se com a fundamentação da moral, não sendo um conjunto de proibições (Gontijo, 2006).

A palavra ética, designa, na tradição filosófica, o objeto de estudo de uma disciplina e o estudo do objeto; disciplina que reflete sobre os modos práticos nos costumes e modos de ser, assim como o saber, em si (Pedro, 2014). E tem por objetivo de sua análise a investigação dos princípios de subsidiam a moral, e para responder aos questionamentos acerca dos modos de viver Schneewind, 1996; Weil, 2012 apud Pedro, 2014).

\section{Diferenças entre Ética e moral}

Agosto (2008, p. 20-22) afirma que:

moral é um conjunto de normas que orientam, disciplinam, normatizam os costumes e as atitudes pessoais ou em grupo, ou como poderíamos dizer, a moral trata do lícito e do ilícito comportamental.... a ética, como uma reflexão sobre as várias morais que são os referenciais para as atitudes, ideias e valores inerentes a todos os povos enquanto demonstradores dos padrões estáveis e de mudança. A ética colhe-os em dados e, nesta coleta, faz a decantação para que se possa separar, juntar, arquivar a várias correntes, estabelecendo os pontos em comum.

Os termos possuem sinônimos em sua origem, porém apresentam alguns aspectos diferenciais: em Hegel, a eticidade é a verdade da moralidade, constituindo sua realização prática, sendo a moralidade um estágio alto de pensamento sobre a liberdade; em Paul Ricoeur, a moral trata da obrigação das normas e deveres e a ética aliada ao bem-viver; e moral como objeto de estudo e ética como estudo do objeto (moral como objeto de estudo da Ética e da Filosofia Moral (Gontijo, 2006).

De acordo com Pedro (2014), a moral é objeto de estudo da ética, complementando-se uma a outra. A ética implica a moral (material de reflexão) e a moral implica a ética para que seja repensada e enquanto a ética é especulativa, a moral é prática, com ações concretas e reais (Pedro, 2014).

A moral está situada no social, legal e cultural enquanto que a ética reflete sobre várias morais como referências para atitudes, ideias e valores das culturas e sociedades diversas (Agosto, 2008).

\section{A Ética no Brasil}

Autores concordam que a ética é um tema problemático para ser discutido na sociedade brasileira devido a ser um problema estrutural desde a gênese da sociedade brasileira, quando o país foi descoberto em 1500 d.C. e colonizado como colônia de exploração.

Lustoza (2013) defende que no Brasil não é possível afirmar que existe uma postura ética de estabilidade pois o país foi sempre utilizado mediante exploração financeira, preferindo o enriquecimento às regras sociais (Lustoza, 2013). 
Silva (apud Lustoza, 2013) afirma que existe dificuldades em debater problemas nacionais sem falar em ética pois é impossível estabelecer comportamentos humanos sem a o entendimento que a ética proporciona, o que Rui Barbosa já havia previsto no começo do século

(...) de tanto ver triunfar as nulidades, de tanto ver prosperar a desonra, de tanto ver crescer a injustiça. De tanto ver agigantarem-se os poderes nas mãos dos maus, o homem chega a desanimar-se da virtude, a rir-se da honra e a ter vergonha de ser honesto (Barbosa, 1914, p. 86 apud Lustoza, 2013, p. 276).

Leonardo Boff (2016) explana que a falta de ética na sociedade brasileira remota aos tempos da colonização, onde o colonizado foi imposto à submissão, e para escapar da punição, era obrigado a mentir, a esconder e fingir, levando a corrupção da mente e rompimento com a ética (Boff, 2016).

\section{Considerações Finais}

A Ética é uma temática abrangente, de muitos desdobramentos, que precisa permanecer em discussões e debates sociais e nas demais áreas de conhecimento e ciências. Sua estreita relação com a moral complementa o conceito e escopo daquela.

Contudo, no contexto brasileiro faz-se necessário maior discussão e debate sobre o assunto para que esse ganhe espaço e possa, por meio do entendimento, trazer mudanças de atitudes coletiva e individualmente.

\section{Referências}

Agosto, M. T. Abs da Cruz. 2008. Ética e relações sociais um enfoque filosófico. In Jacques, MGC., et al. org. Relações sociais e ética. Centro Edelstein de Pesquisas Sociais, 18- 25. <http://books.scielo.org Ética e relações sociais um enfoque filosófico. Maria Teresinha Abs da Cruz de Agosto〉.

Boff, L. Causas da escandalosa falta de ética no Brasil. 2022 Jornal a Gazeta. Espírito Santo, 1 de agosto de 2016. <http://www.ijsn.es.gov.br/ConteudoDigital/20160920_aj04406_etica.pdf..

Gil, A. C. 2008. Métodos e técnicas da pesquisa social. (6a ed.), Atlas.

Gontijo, E. $\quad$ D. 2006, Os 'Ética' $\quad$ termos 'Moral'. $\quad$ Revista
<http://pepsic.bvsalud.org/scielo.php?script=sci_arttext\&pid=S167944272006000200008>.

Rezende, M. B. de. Ética $e$ moral, 2006. Revista Paraense de <http://scielo.iec.gov.br/scielo.php?script=sci_arttext\&pid=S010159072006000300001>.

Lustoza, H. K. A crise ética na sociedade brasileira. 2013 Revista jurídica Unicuritiba. 1(30), 271-283. <http://revista.unicuritiba.edu.br/index.php/RevJur/article/view/563/435>.

Unesco, Ética no Brasil. UNESCO - Construir a paz, nas mentes dos homens e das mulheres, Brasília, 2021. 